\section{Komplett om enslige, mindreårige barn på flukt}

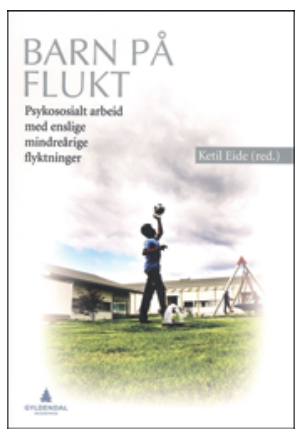

Ketil Eide, red

\section{Barn på flukt}

Psykososialt arbeid med enslige mindreårige flyktninger. 356 s, tab, ill. Oslo: Gyldendal Akademisk, 2012. Pris NOK 499

ISBN 978-82-05-40601-8

Endelig er den her, boken vi har ventet på, kanskje uten helt å vite det. Den er skrevet for et vidt praksisfelt innen barnevern, omsorgsinstitusjoner og kommunalt hjelpeapparat, men vil også være til stor nytte for leger som søker å forstå sine pasienter bedre, enten barna er flyktninger eller asylsøkere.

Innholdet i de fire delene og 15 kapitlene kommer tydelig frem $\mathrm{i}$ innholdsfortegnelsen, noe som gjør boken godt egnet som oppslagsbok. Den dekker alt - hva vi vet om enslige flyktningbarn, flyktningbarn mellom jus, politikk og samfunn, inklusiv barnas stilling i forhold til menneskerettigheter, utlendingslov og rettslig regulering av omsorgssituasjonen. I delen som omhandler det psykososiale arbeidet, drøfter forfatterne utviklingsstøttende omsorg i mottak, veien til bosetting, skolens betydning og ulike terapitilnærminger. I den siste oppsummerende delen drøfter de også etiske og metodiske forskningsmessige utfordringer. Hvert kapittel avsluttes med forslag til utfyllende lesning. Epilogen er en perle, der dagens asylpolitikk speiles i relasjon til vår historie - og barnas.

Forfatterne har oppdatert kunnskap på områdene som de beskriver, og helhetsinntrykket er solid. Noen konkrete pasientforløp og gruppeintervensjoner er illustrert med pasientmateriale og synliggjør på en god måte sammenhengen mellom teori og praksis. Forståelsen av hva som er barns beste i et kulturelt perspektiv, er et viktig tema som de drøfter.

Det eneste jeg savner, i en ellers meget omfattende og grundig, men samtidig lett tilgjengelig håndbok, er et eget kapittel om å arbeide med tolk. Tolkens rolle er imidlertid drøftet i relasjon til enkelte temaer, som forskningsutfordringer.

Dette er en viktig bok i et komplisert felt belemret med mytedannelser. Feltet utfordrer så vel konkret fagkunnskap som hvem vi er som behandlere - i møte med barn i livssituasjoner vi ofte kan ha problemer med helt å ta inn over oss og forstå rekkevidden av.

Jeg anbefaler boken varmt for alle som arbeider med flyktningog asylbarn, eller som bare lurer på hva det innebærer. For barneog ungdomspsykiatere burde den være obligatorisk pensum.

\section{Mest for pårørende?}

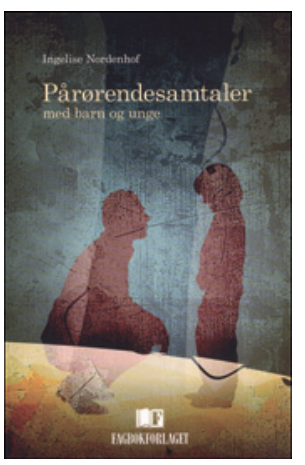

Ingelise Nordenhof

Pårørendesamtaler med barn og unge

226 s, ill. Bergen: Fagbokforlaget 2012.

Pris NOK 289

ISBN 978-82-450-1232-3

Forfatteren er dansk sosionom med tilleggsutdanning og bred klinisk erfaring. Med denne boken, som synes å være en direkte oversettelse av den danske utgaven fra 2008, ønsker hun å bidra til at barn og unge, som lever i familier med foreldre som lider av psykisk eller fysisk sykdom eller ruser seg, kan få hjelp gjennom samtaler. Temaet er aktuelt, og det er klare behov for å øke oppmerksomheten og kompetansen innen dette feltet både hos leg og lærd.

De 12 kapitlene inneholder en rekke beskrivelser av samtaler basert på møter med barn i alderen 1-19 år med eller uten foreldre eller andre til stede. Her er det gode eksempler på utfordringen ved å finne den rette balansen mellom å trekke barnet inn i forhold som angår dem, og beskytte dem fra å bli overinvolvert.

Fremstillingen veksler mellom fortellinger, refleksjoner, teori og metodeavsnitt. Forfatteren begrunner dette med at kapitlene skal kunne leses hver for seg, men fører til gjentakelser som etter min mening ikke bidrar til å øke en samlet forståelse av til dels bredt sammensatte problemområder. Slik synes fremstillingen av utfordringer innen psykiatrisk diagnosesetting mest å ha som målsetting å understreke pasienters og pårørendes rett til å klage.

Forfatteren bygger i sin praktiske tilnærming mye på narrativ metode, godt utformet av Michael White. For øvrig inneholder referanselisten nesten utelukkende publikasjoner innen pedagogikk og psykologi på dansk. Dette gjelder bl.a. også norske bøker som er oppført med danske utgaver.

Målgruppen angis å være profesjonelle helsearbeidere som ønsker å styrke sin faglige og personlige kompetanse i møtet med disse barna og foreldrene, men for meg synes boken bedre egnet for foreldre, besteforeldre og andre innen barnas nettverk som kan ha nytte av å øke sine ferdigheter i samtale med barn og unge, og forstå hvilke utfordringer helsearbeiderne står overfor som barneansvarlige.

\section{Inger Helene Vandvik}

Slependen 